\title{
Linguistic Representation of Power in Edward Bond's Lear: A Lexico-Pragmatic Approach to Critical Discourse Analysis
}

\author{
Ayman F. Khafaga ${ }^{1 \& 2}$ \\ ${ }^{1}$ Department of English, College of Science and Humanities, Prince Sattam bin Abdulaziz University, Saudi \\ Arabia \\ ${ }^{2}$ Department of English, Faculty of Arts and Humanities, Suez Canal University, Egypt. \\ Correspondence: Ayman Farid Khafaga, Department of English Language, College of Science and Humanities at \\ Al- Aflaj, Prince Sattam bin Abdulaziz University, P.O. Box 710, Al-Aflaj 11912, Saudi Arabia. E-mail: \\ a.khafaga@psau.edu.sa
}

Received: September 10, 2019 Accepted: October 9, 2019 Online Published: November 12, 2019

doi:10.5539/ijel.v9n6p404 URL: https://doi.org/10.5539/ijel.v9n6p404

\begin{abstract}
This paper investigates the linguistic representation of power in Edward Bond's Lear (1978). More specifically, the paper tries to explore the extent to which power is linguistically represented manipulatively and/or persuasively by means of specific lexical and pragmatic devices in the discourse of the selected play. The main objective of the paper is to explore how power relations, irrespective of their type, influence the cognitive world of the discourse participants, which in turn attempts a change in their conversational behavior to the extent that allows the acceptance of a specific argument in a particular way. The paper adopts a lexico-pragmatic perspective to Critical Discourse Analysis (CDA), instanced by Fairclough's (1989) lexical model for the analysis of discourse, and the concepts of politeness and face (Thomas, 1995; Yule, 1996a). The main research question of the paper is: to what extent do different power relations, encoded lexically and/or pragmatically, affect the conversational behavior of the play's characters, persuasively and/or manipulatively? Some lexical and pragmatic strategies have been highlighted and then linguistically analyzed to expose their effectiveness in deciphering persuasive and manipulative power relations in the selected play. Among these strategies are: euphemism, myth-making, positive self-presentation and negative other-presentation, and politeness strategies. The paper concludes that power has linguistically been encoded in the discourse of the selected play, both persuasively and manipulatively, to affect a cognitive shift in behavior reflected in the conversational interaction among characters.
\end{abstract}

Keywords: persuasive power, manipulative power, lexical level, pragmatic level, critical discourse analysis, Bond's Lear

\section{Introduction}

Language influences our beliefs, formulates our responses and directs our behavior. Sometimes, language users are confined to a specific type of discourse that may, to varying degrees, comes counter to their cognitive attitudes. This disparity takes place when power relations between discourse participants vary. Drama, being a reflection of real life incidents, is no exception. The characters' conversational behavior within the dramatic genre changes frequently with the change of the dramatic events. This change comes as a result of miscellaneous power relations that are also changed throughout the play, which, in turn, is reflected in different discourse types within the same dramatic work. This paper, therefore, tries to explore the extent to which power is linguistically represented manipulatively and/or persuasively by means of specific lexical and pragmatic devices in the discourse of the selected play. Despite the fact that the play under investigation is a conversational genre, that is, a work of fiction, the paper tries to make a connection between the discursive strategies used in it and those used to determine interactional practices between participants in any real speech event today.

Two main objectives are targeted in this paper: first, to show the extent to which power is linguistically encoded both lexically and/or pragmatically in the conversational discourse of the play and; second, to explore how power relations, irrespective of their type, influence the cognitive world of the discourse participants, which, in turn, attempts a change in their conversational behavior to the extent that allows the acceptance of a specific argument in a particular way. Thus, in its attempt to analyze the lexical and/or pragmatic strategies employed to 
reflect power relations in Bond's Lear, this paper functions to explore the ways through which language is subjugated to issues of power that fit the goals of its users. As such, it clarifies how communication is governed by the access to power that is realized by different linguistic manifestations (lexical and pragmatic).

One main research question is addressed here: to what extent do different relations of power, encoded lexically and pragmatically, affect the conversational behavior of the play's characters persuasively and/or manipulatively? To answer its main research question and to achieve its objectives, this paper adopts a Critical Discourse Analysis (CDA) approach with a special focus on Fairclough's (1989) lexical model for the analysis of discourse, and a pragmatic model instanced by the concepts of politeness and face (Thomas, 1995; Yule, 1996a). The reasons why CDA is adopted as a theoretical approach in the analysis of Bond's Lear in this paper is due to two things: first, CDA is concerned with the exposition of issues related to language, power and ideology with regard to the way language communicates ideology and encodes power; and, second, it offers a way of understanding the way by which language is dexterously employed to produce dominance, to reflect power and to assert it (Fairclough, 1989, 1995; van Dijk, 1993, 1996, 2000, 2014).

The remainder of this paper is structured as follows. Section 2 offers theoretical preliminaries, by focusing on critical discourse analysis and the notion of power in discourse as well as the way it has linguistically been approached in previous literature. Section 3 provides the theoretical framework of the study, by shedding light on Fairclough's lexical model of analyzing discourse within the framework of critical discourse analysis, and by reflecting on the concepts of politeness and face. Section 4 presents the methodology of this paper, which includes its adopted approach, corpus and procedures of data analysis. Section 5 is dedicated to the analysis of the selected data, by highlighting the way through which power relations are linguistically (lexical and pragmatic) encoded in the discourse of the play. Section 6 discusses the findings of the paper. Section 7 concludes the paper and offers some recommendations for future research.

\section{Theoretical Preliminaries}

\subsection{Critical Discourse Analysis}

Critical Discourse Analysis (CDA) has been discussed and approached as an independent branch of discourse analysis by many linguists, such as Fairclough (1989, 1995, 2010); Fairclough and Wodak (1997); Fairclough, Pardo and Szerszynski (2003); van Dijk (1993, 1996, 2000, 2001a, 2014); Weiss and Wodak (2003); Wodak and Meyer (2001); Widdowson (2007), among others. Widdowson (2007) sees CDA as a social and political approach of analyzing language in use that attributes certain ideological meanings to texts derived from their linguistic features. This is also emphasized by van Dijk (2001a), who argues that CDA provides some sort of analytical research that highlights the way language is employed to encode power in texts and talk within different political and social contexts.

According to Fairclough et al. (2003), CDA is critical because it attempts to expose the implicit tactics by which language is involved in social life. As such, CDA discusses notions such as dominance, ideology and power. It is critical because "it is rooted in a radical critique of social relations" (Billig, 2003, p. 38). Widdowson (2007) relates the critical nature of $\mathrm{CDA}$ to the fact that it discusses issues of inequality and injustice in socio-political contexts that target the privileges of the powerful elites without any considerations to anybody else. As such, CDA perceives discourse as a "form of social practice" (Fairclough \& Wodak, 1997, p. 258). van Dijk (2001a) argues that the main function of CDA is to uncover the different ways through which power is produced and reproduced to communicate dominance and inequality. The main concern of CDA then is to show how language reflects relations of power, reproduces dominance, and communicates ideologies.

According to van Dijk (1993, p. 252), CDA aims to discuss the different discourse dimensions of power (i.e., rhetorically and physically) and the ways this power is employed to achieve injustice and inequality. Power abuse here means "dominance" (van Dijk, 1993, p. 255) in order to distinguish it from other forms of power that are legitimate and acceptable such as the power of the parents over their children and the power of the teachers over their students. van Dijk (1993) maintains that CDA is concerned with offering better understanding for social issues in texts and talk that can be arrived at by the discursive and textual analysis of language. In this regard, CDA concentrates on a fundamental understanding of social problems such as power, dominance and inequality. Crucially, CDA deals with these concepts from a deconstructive perspective that allows different interpretations of the same text (Khafaga, 2017a).

Wodak and Meyer (2001) argue that CDA investigates social inequality that is institutionalized by the use and/or abuse of language. They maintain that the defining feature of CDA is "its concern with power as a central condition in social life and its efforts to develop a theory of language which incorporates this as a major premise" (Wodak \& Meyer, 2001, p. 11, my emphasis). Fairclough and Wodak (1997) also stress one major aim of CDA 
as to highlight the important role of language in decoding ideologies communicated by means of different power relations in discourse. Summing up the goals of CDA, Weiss and Wodak (2003) state that CDA is primarily concerned with the analysis of the implicit and the explicit strategies used to reflect power, control, dominance and hegemony in discourse.

\subsection{The Notion of Power in Discourse}

One fundamental element in studying discourse in general, and the conversational discourse in particular, is power. Power has been discussed by many linguists (see Fairclough, 1989; Stark, 1996; van Dijk, 1989, 1993, 1995, 1996, 1997b, 2001a, 2001b; Bloor \& Bloor, 1995; Pardo, 2001; Partington, 2003). All emphasize the connection between discourse and power in the sense that discourse abounds in hidden power relations that need to be revealed through linguistic analysis.

Different definitions have been suggested by linguists for the word power. Weber (cited in Stark, 1996, pp. 3435) defines power as "the capacity of an individual to realize his will, even against the opposition of others." Emphasizing its rhetorical dimension, Stark (1996) states that power is a rhetorical ability of language users utilized to change a specific political situation. Within the framework of CDA, van Dijk (1996, pp. 84-85) proposes a framework for the study of power by laying down the following definitions of the word:

1) Power is concerned with the relations between social groups, institutions or organizations. In this regard, power has a social dimension.

2) The meaning of social power is confined to notions of control and domination practiced by one group or one of its members against another.

3) The practice of dominance is considered a form of social power abuse, and often resulting in social inequality.

4) Powerful participants should have some sort of access to practice their power in discourse.

5) Power is produced and reproduced through dominance and control.

6) Power and domination are usually met by different forms of resistance.

Emphasizing the reciprocal relationship between language and power, Fairclough (2010) discusses two types of power: the first is that one which is found in discourse, and the second is the type of power which is realized beyond the limits of discourse. He clarifies that the first type sheds light on the way through which power is reproduced in discourse, whereas the latter casts emphasis on the effective role played by power to reformulate social institutions within societies. Fairclough (2010) proceeds that power can be acquired, produced, and reproduced in the social struggle among discourse participants. According to van Dijk (2001b), power relations are important in constituting the context of situation in discourse. According to him, these relations can take the formal or the informal mode of discourse production. van Dijk (2001b) further states that power relations cover not only the formal or the informal interaction between participants, but also are manifested in all levels of discourse analysis, including the lexical, the pragmatic, the semantic, etc.

Bloor and Bloor (1995, p. 233) discuss the relationship between language and power by arguing for the assumption that there is a mutual relationship between the two aspects (i.e., power and language) in the sense that each concept influences and is influenced by the other within the realm of discourse. They maintain that the different types of power are represented in discourse in the form of language, that is, power can be reflected in different linguistic manifestations. This can be conducted for the very simple reason that language is a site of power conflict in which participants try to enforce their position, strengthen their social and political status, and, sometimes, impose their cognitive attitudes.

Partington (2003) argues that the concept of power in discourse is argumentative in nature because, for him, it is opposed to the notion of solidarity. It is used to describe the pronouns system of many languages. The concept of power is interpreted in many cases as being "in control of the situation" (Partington, 2003, p. 127). Partington proceeds that power is used to describe the ways through which language users control and dominate the powerless. He, thus, relates power to the notions of control and dominance.

Within the framework of critical discourse analysis, van Dijk (1993) postulates that one characteristic of CDA is to clarify how language is used to confirm, reproduce, or challenge existing power relations of individuals and institutions. He maintains that the task of any discourse analyst is to identify the different relations of power within discourse. The importance of the notion of power to the study of discourse lies in van Dijk's words that "if we want to understand some of the fundamental functions of discourse in interaction and society, further insights into the nature of power is needed" (van Dijk, 1997b, p. 16). He suggests that the kind of power relevant to the study of discourse is "social power" which he defines as "a specific relation between social groups or 
institutions" (van Dijk, 1997b, p. 17). One major concept of social power is "control". According to van Dijk (1997b, p. 17), "one group has power over another group if it has some form of control over the other group...we control others if we can make them act as we wish (or prevent them from acting against us)".

\subsection{CDA and Power}

Power is considered one of the "cornerstones of CDA" (Weiss \& Wodak, 2003, p. 11). Pardo (2001) points out that CDA examines the various types of power use and abuse in discourse, whereas Fairclough $(1989$, p. 43) argues that the relationship between power and language is realized in two aspects: "power in discourse" and "power behind discourse." Fairclough clarifies that power in discourse, on the one hand, perceives discourse as a site for power production and consumption; that is, how power is exercised and reproduced within discourse itself. Power behind discourse, on the other hand, focuses on the ways through which power relations are structured and institutionalized in different societies and institutions, and how these institutions in turn are shaped by the various dimensions of power. As such, power can be said to be discursive, socialized, institutionalized, politicized, etc. He emphasizes that whether power is realized in discourse or behind discourse, it is always held, gained and communicated in social struggles. van Dijk (2001b) also states that identifying the relation between participants in discourse is important to determine the context of situation where a social struggle is held. These relations have different manifestations: formal, informal, institutionalized, or otherwise. He further clarifies that:

The representation of such relations in context models controls virtually all levels of discourse, and not only the typical properties of formal or informal speech, or politeness forms. Power or dominance may be expressed or enacted virtually everywhere in intonation, syntax, lexicalization, semantics, pragmatics, and in many aspects of conversational interactions. (van Dijk, 2001b, pp. 22-23, my emphasis)

The relationship between language and power is also emphasized by Bloor and Bloor (1995) who postulate that power, whether politically-based or socially-oriented can be expressed in language, and language can reciprocally reinforce such power. They clarify that language is the site where different relations of power is practiced over individuals with different social roles, and in particular social situations, that is because language is "a site of and a stake in class struggle and those who exercise power through language must constantly be involved in struggle with others to defend (or lose) their position" (Fairclough, 1989, p. 35).

\section{Theoretical Framework}

The theoretical framework of this paper adopts two levels of analysis to investigate the linguistic representation of power in the selected play: the lexical and the pragmatic. The lexical level, on the one hand, shows the importance of lexis in reflecting power relations in discourse and the way words are carefully selected and ideologically employed to shape responses and change attitudes. This level covers three main strategies: euphemism, myth-making, and positive self-presentation and negative other-presentation strategies. The pragmatic level, on the other hand, deals with some pragmatic strategies that are relevant to the study of power in conversational discourse. This level focuses on politeness strategies that will be discussed in relation to Face Threatening Acts (FTAs). Now, it is time to reflect theoretically on these strategies, i.e. the lexical and the pragmatic.

\subsection{A Lexical Approach to CDA}

On the lexical level, Fairclough (1989, pp. 110-111) lists some questions that are analytically relevant to the critical study of language. These questions present different textual features that prove useful in clarifying the implicit and the explicit features of texts through linguistic analysis. Fairclough's questions are as follows:

(a) What experiential values do words have?

What classification schemes are drawn upon? Are there words which are ideologically contested? Is there rewording or overwording? What ideologically significant meaning relations (synonymy, hyponymy, antonymy) are there between words?

(b) What relational values do words have?

Are there euphemistic expressions? Are there markedly formal or informal words?

(c) What expressive values do words have?

(d) What metaphors are used? (italics in original)

Fairclough $(1989,2013)$ identifies three values through which the use of words is relevant to the critical analysis 
of language use. They are experiential, relational and expressive. Fairclough's values emphasize the importance of vocabulary in the process of analyzing a text. He highlights the effectiveness of using words in conveying the ideological state of the speaker. Fowler (1996) proposes that lexis is skillfully selected to carry ideological concerns of the speaker. Emphasizing the significance of vocabulary in the process of practicing power, Schaffner (2004) argues that discourse analysis concentrates on the dexterous employment of vocabulary to achieve particular goals of their users. Among the lexical strategies that are employed in the selected play to communicate power are: euphemism, myth-making, and strategies of positive self-presentation and negative other presentation. These are discussed in the subsections below.

\subsubsection{Euphemism}

Euphemism is a ploy that primarily depends on the use of words. Brembeck and Howell (1952, p. 157) define the term as a "language device chosen because it is more socially acceptable than its synonyms." They argue that a euphemistic expression "is usually an avoidance of direct communication" (Brembeck \& Howell, p. 157). For Fairclough (1989), euphemism refers to the process in which specific words are employed to avoid the negative values pertaining to the offensive meaning of these words. To Allan and Burridge (1991, p. 11) any euphemistic term is used as "an alternative to a dispreferred expression, in order to avoid possible loss of face: either one's own face or, through giving offense, that of the audience or of some third party".

In Orwell's words, "euphemism is designed to make lies sound truthful and murder respectable" (cited in Hirschberg \& Hirschberg, 1999, p. 501). Orwell sees that when language is biased towards a specific ideological agenda, euphemism is used to hide the intended meaning of the speaker. He proceeds to state the fact that political language always needs some linguistic solutions that can disguise realities and hide intentions as it is "the defense of the indefensible." Thus, political language "has to consist largely of euphemism, question-begging and sheer cloudy vagueness...The great enemy of language is insincerity" (cited in Hirschberg \& Hirschberg, 1999, p. 508). There are certain motives for using euphemism; sometimes, euphemism is used to avoid offending the sensibilities of others, in some other situations, euphemism is used to mask reality, to hide facts and to deceive.

\subsubsection{Myth-Making}

Myths created by politicians are "ways of communicating ideology" (Charteris-Black, 2005, p. 22). They are instruments to practice power as they are used by those in power "to dominate the public" (Khafaga, 2017b, p. 189), "to legalize the illogical" and "to defend the irrational" (Khafaga, 2017b, p. 192). Myth "is a story that provides an explanation of all the things for which explanations are felt to be necessary" (Charteris-Black, p. 22). Within the framework of politics, Flood (1996) argues, a myth is an ideology-oriented discourse that intentionally functions to provide explanation for some events in the past or the present, and other expectations for the future that are perceived and accepted as valid by a specific group. Jowett and O'Donnel (1992, p. 215) reinforce Flood's argument concerning political myth saying that "it is a story in which meaning is embodied in recurrent symbols and events." Barthes (1972) also casts emphasis on the important role of intention in propagating myths. He clarifies that political myths are types of discourse that are calculated by the degree of intentionality of their launchers rather than by their literal meaning.

Edelman (2001, cited in Charteris-Black, 2005, p. 25) identifies three particular political myths. First, the myth of the Conspiratorial Enemy, which refers to the idea that there is always an outside enemy plotting against an in-group by planning violent attacks and harmful acts, both physically and ideologically. Second, the Valiant Leader myth, which presents a benevolent leader who is ready to sacrifice soul and body to save his people, and who is competent enough to lead people, solve problems, stop violence and overcome difficulties. Third, the United We Stand myth, which communicates the idea that one group, a country or party, can achieve success over its opponents by a complete compliance to their leader and an acceptance to the regime's rules.

\subsubsection{Positive Self-Presentation and Negative Other-Presentation}

Presenting oneself positively and others negatively is one of the most valuable ways of analyzing forms of rhetorical power. van Dijk (1997a, p. 36) points out that positive self-presentation strategy means "self-glorification," and demonstrates that it "often functions as a strategic disclaimer that introduces sequences of negative other-presentation." Within these two processes, van Dijk (1993) proceeds that "models are being expressed and persuasively conveyed that contrast 'US' with 'THEM', for example, by emphasizing 'our' tolerance, help, or sympathy and by focusing on negative social or cultural differences, deviance or threats attributed to 'them"' (p. 263, capitals in original).

To van Dijk (1997b), the representation of an individual, a group or a political party positively or negatively 
attempts a change in behavior on the part of the public that functions to shape and reshape their attitudes concerning particular issues. This change comes as a result of a cognitive shift in attitudes that makes them accept an argument in a particular way. The aim beyond using some discursive strategies to present the in-group positively and the out-group negatively is the fact that powerful discourse participants (i.e., rhetorically) always tend to mollify their actions by attributing good qualities to the in-group, and vilify others' action by undermining their actions. This mollification and vilification process ultimately targets a shift in the cognitive background of the recipients (i.e. their schemata) towards the addressed issues in discourse.

van Dijk (1997b, p. 264) states that speakers may use some tactics in order to present themselves positively and their opponents negatively, such as the following:

(a) Argumentation: the negative evaluation follows from the 'facts'.

(b) Rhetorical figures: hyperbolic enhancement of 'their' negative actions and 'our' positive actions; euphemisms, denials, understatements of 'our' negative actions.

(c) Lexical style: choice of words that imply negative (or positive) evaluation

(d) Story telling: telling above negative events as personally experienced; giving plausible details above negative features of the events.

\subsection{A Pragmatic Approach to CDA}

This level is concerned with "the study of linguistic communication in context" (Blum-Kulka, 1997, p. 38), or as Mey (1993, p. 5) puts it, pragmatics is the science which studies "language seen in relation to its user." Yule (1996a, p. 127) defines the term as "the study of "intended speaker meaning." He clarifies that pragmatics is greatly concerned with the intended meaning of the speakers/writers. This approach provides linguistics with many aspects relevant to the study of power relations in discourse. Among these strategies that will be employed in the analysis of this paper are politeness and face-threatening acts.

\subsubsection{Politeness}

Politeness is an important tool in the hands of those who tend to use power persuasively. Speakers, especially politicians, used to employ certain politeness strategies to make their participants identify themselves with their desires. The relationship between discourse and politeness is evident because no persuasive discourse can be free from politeness strategies. Yule (1996a) argues that politeness phenomenon is governed by social aspects because the relationships between discourse participants are the criterion upon which their communication and interaction are pragmatically judged. Yule (1996a) states that any linguistic interaction is perceived from its social dimension, and any sort of language used by speakers is determined by the degree of the relationship between discourse participants. This relationship is governed by particular aspects, such as the degree of power, age, authority and access to discourse.

For Partington (2003), politeness is a linguistic phenomenon that addresses the different concepts of social behavior, such as solidarity, distance and deference. Politeness can be accomplished in situations of social distance and closeness, or what Yule (1996a, p. 61) calls "deference" and "solidarity." 'Deference' is the state at which the speaker shows awareness for another person's face when that other seems socially distant, while 'solidarity' means showing awareness when the other is socially close. The participants in an interaction then "often have to determine as they speak, the relative social distance between them, and hence their "face wants" (Yule, 1996a, p. 61). Brown and Levinson (1987) provide a well-known account of politeness and suggest that politeness "is a universal phenomenon, affecting linguistic and other social behavior" which is based on the concept of face (cited in Short, 1996, p. 212). Yule (1996b, p. 134) points out that "your face, in pragmatics, is your public self-image" which means "the emotional and social sense of self that every person has and expects everyone else to recognize".

Within the framework of politeness, face "is best understood as every individual's feeling of self-worth or selfimage" (Thomas, 1995, p. 169), which can be communicated, maintained and improved by means of interaction with others. According to Brown and Levinson, face is of two aspects: positive face and negative face. Positive face says "I have my own value systems that I don't want challenged. I want my contributions valued and appreciated", while negative face says "no one has the right to tell me what to do. I do not like to be imposed on" (Brown \& Levinson, 1987, cited in Pridham, 2001, p. 52). For Short (1996, p. 213), Positive face "is our need for our actions and wants to be desirable to other people as well as ourselves," whereas negative face "is the wish that our actions should be unimpeded by others." Furthermore, Flowerdew $(1999$, p. 10) emphasizes that positive face means the desire of the speaker "to be unimpeded," whereas negative face means the desire of the speaker "to be approved of". 


\subsubsection{Face-Threatening Acts}

Thomas (1995, p. 169) defines 'face-threatening acts' (FTAs) as acts which are "liable to damage or threaten another person's face." Thomas maintains that there are four possibilities to perform the FTAs: either to perform them using 'on-record' strategies' or to perform them by means of 'off-record' strategies. The 'on-record' strategies include: bald on-record, positive politeness and negative politeness, whereas the 'off-record' strategies are delivered when the speaker decides to avoid the FTA altogether in time when the degree of face threat is too great. In this case, the speaker tends to "say nothing" (Thomas, 1995, p. 169). Blum-Kulka (1997, p. 51) supports Thomas' division of FTAs but he classifies them into five categories: "bald on-record strategies, positive politeness, negative politeness, off-record strategies and opting out".

Bald On-record Strategies refer to discursive situations where speakers decide to ignore face risk and thus speak directly (Thomas, 1995). Yule (1996a) sees the strategy as the expressions that are related to situations where the speaker is more powerful than his/her recipients, and believes that he has the ability to influence them and control their behavior rhetorically, i.e. by means of using particular lexis. Sometimes, the 'bald on-record' expressions are followed by some expressions like 'please' and 'would you?' which function 'to soften the demand and are called mitigating devices" (Yule, 1996a, p. 63).

In Positive Politeness, for Thomas (1995, p. 171), speakers can "perform an FTA with redress." This strategy "appeals to the speaker's desire to be liked and approved of" (Thomas, 1995, p. 171). Brown and Levinson (1987) also state that by using positive politeness the speaker deals with the hearer as an in-group member or a friend whose desires and needs are always known and liked. For Yule (1996a, p. 64), positive politeness leads the speaker to appeal to a common goal, and even friendship, via expressions that claim "common ground." He points out that when speakers tend to use positive politeness strategies, they try to express closeness between them and their addressees which in turn can be perceived as "a solidarity strategy" (Yule, 1996a, pp. 65-66). This solidarity can be marked in discourse by the employment of some terms such as the inclusive 'we' and the metalinguistic directive 'let's'.

Negative Politeness, according to Yule (1996a, p. 62), "is oriented to the person's negative face" as it attempts to demonstrate respect and consideration for others' time or concerns, and, sometimes, communicates apology for any interruptions or imposition during the act of communication. For Blum-Kulka (1997), negative politeness functions to create some sort of satisfaction to the negative face of hearers as well as their need to be free from imposition. This is supported by Thomas's (1995) argument that negative politeness advocates the hearers' rights not to be interrupted or impeded; that is, to feel free to act and speak the way they choose. Yule (1996a, p. 66) also supports the idea of the freedom of choice on the part of the hearers as he emphasizes the idea of independence that should be found between speakers and hearers in discourse. Yule (1996a, p. 66) sees such an independent nature of communication as "a deference strategy" that functions to emphasize the absence of "personal claims" between discourse participants.

Blum-Kulka (1997, p. 50) defines the Off-record Strategies as the state of "realizing the act so indirectly that speakers cannot be made accountable of any specific communicative intent." By using this strategy, speakers tend to convey their communicative acts and express their needs in an indirect way. Short (1996a, p. 214) argues that speakers who employ this strategy are "merely stating what the case is rather than asking or telling someone to get on with the work." Yule (1996a, p. 63) states that 'off-record' strategies are "ways of expressing your needs by addressing others indirectly" and maintains that if the other person responds to such off-record strategy, then "it will be because more has been communicated than was said".

\section{Methodology}

\subsection{Data Description and Procedure}

The corpus which this paper analyzes constitutes one play written by Edward Bond in 1978: Lear. The play consists of 18 scenes distributed in three acts. 7 scenes comprise Act One, 7 scenes are dedicated to Act Two and 4 scenes form Act Three.

The procedure adopted in this paper is based on two analytical strands: the first sheds light on the lexical strategies constituting power relations. The second strand presents the pragmatic strategies that reflect the same power relations in the play under investigation. Crucially, by highlighting both the lexical and the pragmatic tactics of power, the analysis tries to show how these strategies (lexical and pragmatic) are incorporated to represent the rhetorical dimension of power, which is reflected both persuasively and/or manipulatively throughout the dramatic dialogue of the play.

Two reasons constitute the rationale for selecting this play in particular. First, the play abounds in lexical and 
pragmatic tactics that reflect the rhetorical dimension of using power in discourse. Second, the play presents two types of discourse, each of which pertains to one specific dimension of power: the discourse of oppression, which dominates the first part of the play and is characterized by the way power is rhetorically employed to manipulate (the manipulative dimension of power); and the discourse of revolt, which shows the extent to which power is utilized to persuade (the persuasive dimension of power). Thus, Bond's Lear provides a type of ideological discourse that can be said to be worthy of linguistic research. Conducting a linguistic investigation of this play might help to decipher the deceptive tactics and misleading information that basically depend on the power of the word.

\subsection{Bond's Lear: A Brief Account}

Bond's Lear is a cunning reinterpretation of Shakespeare's King Lear. The play is one of the most popular dramas in modern literature as it is a new version of Shakespeare's masterpiece. The play shows an authoritarian king and a powerful ruler who decides to build a great wall around his kingdom believing that such a wall will ensure both peace and security for his people against his enemies. Unfortunately, instead of securing his people, the wall enslaves them. Bond manages to retain the basic narrative structure of King Lear. He keeps the names of some characters like Lear and Cordelia, the roles of some characters like those of the two daughters who are presented by their prototypes: Bodice and Fontanelle, and the Fool whose role is played by the Gravedigger's Boy, and finally the theme of ingratitude.

In Lear, Bond traces the growth of organized and developing resistance to a repressive government, a system which becomes very clear in the last scenes of the play. Bond's Lear is concerned with different kinds of political oppression. It shows the introductory measures that people have to do if they really seek a change in their societies. The play demonstrates that conflict lies not in human nature but in the constrictions imposed upon it by society or, to be more accurate, by the established system. The end of Bond's Lear shows that it is difficult to act against the regime; but it also demonstrates that action in an unjust society is the only moral response in such a situation, because a repressive political system allows no freedom, so action is difficult and the possibility of change may take a long time.

\section{Analysis}

\subsection{Lexical Level}

This level presents a number of lexically-based CDA strategies relevant to the study of power in Bond's Lear. Among lexical strategies discussed in this part are: euphemism, myth making, positive self-presentation and negative other-presentation strategies. This level shows how words are crucial in exercising power and communicating ideologies.

\subsubsection{Euphemism}

CDA analyzes euphemism as one among different lexical choices used by powerful speakers to obscure the unfavorable components of their actions. In Bond's Lear, many characters use euphemistic terms in an attempt to mask reality and to cover deception and oppression. Lear, Warrington, Fourth Prisoner, and other characters use euphemism to deceive and to impede understanding of their recipients so as to make them unable to grasp the real meaning beyond such euphemistic terms, and to limit their ability to criticize. Here are some examples:

Extract (1)

Lear. I started this wall when I was young. I stopped my enemies in the field, but there were always more of them. How could we ever be free? So, I built this wall to keep our enemies out. My people will live behind this wall when I'm dead. You may be governed by fools but you'll always live in peace. My wall will make you free. (Lear, p. 3, my emphasis)

The idea of euphemism is clearly shown in Lear's attempt to defend the act of building the wall during which many workers are killed. Lear uses the word free to euphemize the consequences that took place as a result of building such a wall. He tries to defend this illegal act of killing by using his rhetoric in an attempt to manipulate his recipients into accepting the idea that walls will bring peace and security for them. Here, euphemism, being a tactic of rhetorical power, is used to mask reality, to cover oppression and to mollify the bitter facts so as to be accepted quite willingly. Euphemism, therefore, is used to manipulate rather than to persuade. Lear utilizes it to influence the minds of his addressees by highlighting the positive side of his project; that is, of freedom that he promises to be the ultimate result of building the wall. This promise is emphasized by the use of the truth modal will which signifies a high level of certitude. 
Extract (2)

Lear. Shoot him!

Bodice. No!

Lear. This is not possible! I must be obeyed!

Warrington. Sir, this is out of hand. Nothing's gained by being firm in little matters. Keep him under arrest. (Lear, p. 6, my emphasis)

Bodice, Warrington and Lear are talking to each other concerning Lear's decision to kill a worker because he slacks work on the wall. Lord Warrington, one of Lear's companions, interferes to soften the situation between Lear and his daughter informing the former that he will gain nothing out of this clash, describing Lear's insistence on killing the worker by the euphemistic term little matters which aims to soften the situation and to mask reality because killing a man is not by all means a little matter. Warrington's use of euphemism functions to make Lear give up his decision and to comply with his daughter's request. Thus, euphemism in little matters is also used to manipulate.

Extract (3)

Fourth Prisoner. Understand, this isn't an instrument of torture, but a scientific device. See how it clips the lid back to leave it unmarked. (Lear, p. 63, my emphasis)

The Fourth Prisoner continues the use of euphemism to achieve manipulation. The Fourth Prisoner, who is the doctor of the prison, is given orders from the new government to blind Lear to make him "politically ineffective" (Lear, p. 62). He uses euphemism to hide the fact of a device which is used for removing human eyes. His statement this isn't an instrument of torture, but a scientific device signifies to mollify the real purpose of such a device. He tries to cover the bloody connotations of the word torture, and to attribute good connotations to his speech via using the word scientific instead in an attempt to deceive Lear and to impede his understanding.

\subsubsection{Myth-Making}

A significant strategy of using the rhetorical power of lexis to achieve manipulation in Bond's Lear is the myth of 'the conspiratorial enemy'. This political myth is realized in the play both literally; by building the wall, which is considered to be the main idea around which the whole action of the play revolves; and ideologically, by propagating the idea of peace and security to be the excuse for any mischievous acts. In dictatorial societies, myths are often created by the ruling parties to defend and justify the irrationalities committed against the public. In the case of Bond's play, Lear launches the myth of 'the conspiratorial enemy' to compel his people to accept his decisions without any objection. Lear starts his myth at the very beginning of the play when he announces:

I started this wall when I was young. I stopped my enemies in the field, but there were always more of them. How could we ever be free? So, I built this wall to keep our enemies out. My people will live behind this wall when I'm dead. You may be governed by fools but you'll always live in peace. (Lear, p. 3, my emphasis)

The king tries to justify the act of building the wall during which he sacrifices many souls. The old king attempts to implant within the minds of his recipients his mythical belief that walls bring peace and security. Lear confines himself within a mythical belief that walls protect people from outsiders, he tells his people that when he is dead, they may be governed by fools, and assures them that they will always live in peace. Lear supports his assumption by the truth modal will to convey certitude, and the use of the adverb always to indicate consistency.

The old king continues to propagate his myth that walls bring both peace and security by emphasizing the existence of an outside enemy represented in the duke of North and the duke of Cornwall. Speaking of their enmity, Lear says:

They're my sworn enemies. I killed the fathers therefore the sons must hate me. And when I killed the fathers I stood on the field among our dead and swore to kill the sons! I'm too old now, they've fooled me. But they won't take my country and dig my bones up when I'm dead. Never. (Lear, p. 5, my emphasis)

Announcing that the two dukes are his enemies against whom he is building his wall, Lear tries to communicate the belief that the wall is the only shield that brings peace and security. If his people adopt the same mythical belief, they will accept any sacrifices and irrationalities without any objection. The use of the truth modal will in the negative form is to communicate to his recipients his competency in defending their country, and his enemies' incompetency to invade his country. It also aims to inform them in an indirect way that building the wall is a precondition of defending the country. 
One interesting thing about the discourse of Lear is that the word wall, which Lear uses in the discourse of oppression to propagate his myth, is also employed by the same person in the discourse of revolt to put an end to this myth. The old king uses the same word wall in his revolution against the new government led by Cordelia. Now, after his overthrow, Lear's discourse is completely different, that is, his utterances I must build the fortress (Lear, p. 5), and my wall will make you free (Lear, pp. 3-4) in the discourse of oppression are shifted to be don't build the wall (Lear, p. 84), and the wall will destroy you (Lear, p. 84) in the discourse of revolt.

\subsubsection{Positive Self-Presentation}

Positive self-presentation is a strategy that depends entirely on the use of words to beautify oneself. In Bond's Lear, certain CDA strategies are employed to present some characters positively. This section presents two strategies that are used in the play to practice power both persuasively and manipulatively: competency and promises.

\subsubsection{Competency}

Throughout Bond's Lear, both Lear and Cordelia make use of some discursive devices to prove their competency in an attempt to express their ability to lead the country. This strategy is used in the play to reflect power persuasively. Consider the following extracts:

Extract (1)

Bodice. Father, if you kill this man it will be an injustice.

Lear. My dear, you want to help me, but you must let me deal with the things I understand. Listen and learn. (Lear, p. 4, my emphasis)

Lear's let me deal with the things I understand is an attempt to show that he is more competent than his daughter, Bodice. The king tries to prove his experience in the government's affairs. He attempts to emphasize his ability in dealing with critical moments in order to make his daughter give up her objection, and comply with what he is going to do. Lear's aim beyond showing his competency is to persuade Bodice of the legitimacy of the crime he intends to commit against the worker, and to beautify his picture before his daughter. The use of the first-person singular pronoun 'I' in I understand functions to reinforce Lear's attempt to appear as being competent.

Extract (2)

Cordelia. You only understand self- pity. We must go back, the government's waiting. There are things you haven't been told. We have other opponents, more ruthless than you. In this situation a good government acts strongly. I know you wouldn't cooperate, but I wanted to come and tell you this before we put you on trial: We'll make the society you only dream of. (Lear, pp. 84-85, my emphasis)

In her discussion with Lear concerning her policy in leading the country, Cordelia tries to prove her competency as a state governor and her skill in leadership. Cordelia's we have other opponents, more ruthless than you and in this situation a good government acts strongly function to show her willpower determination and her ability to deal with any future circumstances. Her words also implicate that her new government is better than Lear's in an attempt to communicate to the former king that she is more competent than him in leading the country. Cordelia's we'll make the society you only dream of has two functions: first, to highlight Lear's failure to create the society he wants; and second, to emphasize her ability to establish such a society. The connection between the first-person plural pronoun 'we', and the truth modal 'will' in we'll signify to highlight Cordelia's ability and determination to execute what Lear fails to carry out. Thus, showing competency aims to present the speaker positively.

\subsubsection{Promises}

One fundamental fact about politicians in any dictatorial government is that they are always promise-bearers. These promises are usually delivered to presage better conditions in the future. This in turn makes it easy for politicians to persuade their addressees of what they want, and to make them acknowledge the availability and consistency of their policies. In Bond's play, Lear uses this strategy to propagate his policy, especially with regard to the act of building the wall: "you'll always live in peace," "you'll live inside a fortress" and "my people will live in freedom and peace" (Lear, pp. 3, 4, 5, 7, respectively). Lear's three statements carry promises of peace, security and freedom. These promises have two functions: to maximize the purpose beyond building the wall as being the only shield against any future attack, and to minimize the contempt of his people against building the wall. Lear tries to force his people via these promises to work hard and suffer patiently for the purpose of building the wall which, in turn, will bring them peace and freedom. The king attempts to communicate that the existence of the wall is a precondition for attaining peace and freedom. This positive 
presentation aims to get his people manipulated into the legitimacy of building the wall.

\subsubsection{Negative Other-Presentation}

Negative other-presentation is another strategy which tends to misrepresent others in order to weaken their status. This strategy is realized in Bond's Lear through two CDA's tools: accusation and criticism.

\subsubsection{Accusation}

A number of accusations have been launched against the duke of Cornwall and the duke of North by Lear in an attempt to vilify the two men before his two daughters when he knows that they are going to marry them. Lear's accusations aim to misshape the two men's position in order for his daughters to end their relation with the dukes. Consider the following extracts:

Extract (1)

Lear. I know it would come to this! I know you were malicious! I built my wall against you as well as my other enemies! You talk of marriage? You have murdered your family. There will be no more children. Your husbands are impotent. You will get nothing from this crime. (Lear, p. 7, my emphasis)

After the two daughters had married the duke of Cornwall and the duke of North, Lear started his vilification campaign by reminding his daughters that the two men are his enemies against whom he is building his wall. Lear begins to vilify the picture of the two dukes in an attempt to persuade his daughters to end their marriage. Lear's your husbands are impotent is a clear accusation which functions to enfeeble the two dukes' position. He describes their marriage from the two men as a crime, then he emphasizes that they will get nothing from this crime. All these utterances aim to present the two dukes negatively in order to influence his daughters' attitude so as to make them end this marriage. Directing accusations against others signifies to influence the cognitive schemata of the recipients in a manipulative way that makes them reshape their response.

\subsubsection{Criticism}

Cordelia's policy in running the country after she seizes power has severely been criticized by Lear in the discourse of revolt to prove her inability in leadership. Consider the following extracts:

Extract (1)

Lear. There's nothing I can do! The government's mad. The law's mad. (Lear, p. 79, my emphasis)

Extract (2)

Lear. It's strange that you should have me killed, Cordelia, but it's obvious you would. How simple! Your law always does more harm than crime, and your morality is a form of violence. (Lear, p. 85, my emphasis)

Lear's the government's mad and the law's mad in the first extract and your law always does more harm than crime, and your morality is a form of violence in the second extract function to present Cordelia negatively in order to highlight the irrationality of her regime which is characterized by violence and oppression. Lear's words are also meant to associate Cordelia's regime with all kinds of evil, violence and oppression in order to weaken her policy as well as her political status before her people which, in turn, facilitates his task in persuading his recipients of what he wants. The only aim beyond Lear's criticism against Cordelia's regime is to communicate that her rule is characterized by violence and oppression. The king then tries to instigate his people to revolt against Cordelia's government.

\subsection{Pragmatic Level}

This level discusses some pragmatically-based CDA strategies that are relevant to the study of power in Bond's Lear. These discursive strategies include: politeness strategies, particularly face- threatening acts.

\subsubsection{Face-Threatening Acts}

Three strategies are analyzed in this part: off-record, positive politeness, and negative politeness strategies. The use of these strategies varies from one participant to another according to the degree of power.

\subsubsection{Off-record Strategies}

Lear uses the off-record strategies in the discourse of revolt in which he is wrested of his power and authority. This strategy is usually attributed to those who are powerless, or those who have less power. It is an indirect way of demanding something. Consider the following example: 
Lear. It's so simple and easy here. But where shall I go now, how can I live, what will become of me?

Boy. Stay here. You can look after my pigs. I can't pay you but you can eat and sleep with us. (Lear, p. 25, my emphasis)

Wrested of his power, Lear remains helpless and desperate; his army is defeated and he finds himself homeless overnight. The old king realizes his new situation, so he stops giving orders, and resorts to a new discursive device that copes with his new status and achieves his purposes. Lear uses the off-record strategy to convince the Boy to offer him what he wants. Lear's it's so simple and easy here emphasizes his intention to be as indirect as he can since he no longer has power. He uses the off-record strategy to convey to the Boy his need for a place to stay in because he becomes fugitive. Lear states that the Boy's house is so simple and easy because the Boy and his wife looked after me well. Lear then entails his speech with the questions where shall I go now and how can I live, what will become of me? that seek no answer but stimulate the Boy's sympathy so as to make him fulfill his needs by offering him a place to live in. Lear succeeds in realizing what he wants since the Boy's reply comes very soon as stay here, you can look after my pigs and I can't pay you but you can eat and sleep with us.

\subsubsection{Positive Politeness}

Positive politeness strategies are used in Lear to achieve pure persuasion and are often attributed to powerless characters. These strategies, therefore, are relevant to the discourse of revolt that dominates the second part of the play. Consider the following extracts:

Extract (1)

Lear. I could have a new life here. I could forget all the things that frighten me ...I must forget it all, throw it away! Yes! Let me live here and work for you. Boy. Good. You'll be a real help to me when you have settled in. I'll be able to clear some more fields. (Lear, p. 25, my emphasis)

Lear is talking to the Boy about his past experiences as well as his hopes in the future. At first, Lear uses the off-record strategy stating that he could have a new life in the Boy's house and that he could forget all the things that frighten him; then he entails his speech with the positive politeness strategy in let me live here and work for you to stimulate the Boy's sympathy so as to stay in the latter's house. Without the positive politeness strategy, Lear's utterance would be 'I want to live here', but the old king realizes his new situation as a deposed king, so he prefers to be indirect via the positive politeness strategy to make the Boy fulfill his needs. The use of this strategy indicates that Lear no longer uses directive expressions as he used to when he had power. This strategy also marks a development in Lear's character; he prefers to be more polite because it is the most appropriate manner he can adopt to attain his goals.

The same indirectness in conversational behavior is conveyed by the Boy's wife when she tells Lear: "I suppose you'll go away now after last night" (Lear, p. 24) in an attempt to convey that his stay in her house is undesirable. She uses the positive politeness strategy to communicate her desire to make him leave the place. Without the positive politeness strategy, the wife's utterance would be: "go away now," but she avoids using the bald on-record strategy and tries to be more polite in order to persuade Lear of what she wants.

\subsubsection{Negative Politeness}

Negative politeness strategy is employed when the speaker knows that he has less power and authority than his participant. In such a case, the speaker tries to be more polite when addressing others who are more powerful than him in order to attain what he seeks.

\section{Extract (1)}

Lear. I'm hungry. I Know you have no pity to sell, there's always a shortage of this in wartime, but you could sell me some bread. (Lear, p. 17, my emphasis)

Lear uses the negative politeness strategy in I know you have no pity to sell, there's always a shortage of this in wartime, but you could sell me some bread to convey to the Boy his belief that he shares him the same idea that there is a shortage of food during wars in an attempt to establish a common ground with the Boy to make him comply with his desire. Without the negative politeness strategy, Lear's utterance would be sell me some bread, but the deposed king knows that indirectness is the most appropriate polite manner to achieve his goals.

Extract (2)

Lear. Can I rest in your house? I'm so tired.

Farmer. Yoo'd be welcome. (Lear, p. 65, my emphasis)

Lear asks for the Farmer's permission to let him rest in the latter's house by using the negative politeness 
strategy in can I rest in your house? which functions to arouse the Farmer's sympathy with him. Lear tries to persuade the Farmer to let him stay in his house. Without the negative politeness strategy, the utterance would be open your house to have some rest in, but the old king knows that the bald on- record strategy does not suit his new situation because he loses all his power and authority, so he decides to be more polite with the Farmer by using the negative politeness strategy to make others accept what he is going to deliver.

\subsubsection{Other Politeness Strategies}

This part presents two strategies: the use of rhetorical questions and gap bridging.

\subsubsection{Rhetorical Questions}

Lear uses rhetorical questions to practice his power manipulatively as a king. Rhetorical questions are considered to be an indirect way for demanding something. They are often used by persons who are rhetorically powerful to motivate their recipients to accept their arguments. Consider the following:

Extract (1)

Lear. ... I stopped my enemies in the field, but there were always more of them. How could we ever be free? So, I built this wall to keep our enemies out. (Lear, p. 3, my emphasis)

Lear's rhetorical question how could we ever be free? does not seek or expect any answers on the part of his addressees. However, he wants them to think in the way he wants and to agree to his policies with regard to the act of building the wall in particular. Lear's question is employed to defend the atrocities he has been committing against his people during the process of building. The old king tries to urge his recipients to confess that they will not be free unless he builds the wall. Lear's use of the first-person plural pronoun 'we' in his question functions to make his recipients feel that both he and them are in the same boat, share the same fate, and face the same problem represented in the existence of an outside enemy ready to attack them if the wall is not completed. In this way, Lear tries to manipulate his people and to dominate their minds, but in a more polite manner.

\subsubsection{Gap-Bridging}

Gap-bridging is a strategy of politeness speakers use to narrow the gap between them and their recipients. This strategy is used in Bond's Lear to produce manipulation. Consider the following:

Extract (1)

Lear. Greetings to the eighth regiment! (Still saluting. To Warrington.) You will command my right flank and circle them on the right. Then I attack the centre. That's how I crushed the fathers. (Still saluting and waving) I salute my loyal comrades! (Lear, p. 8, my emphasis)

Attempting to narrow the gap between him and his subjects, Lear uses the gap-bridging strategy in I salute my loyal comrades to create an access to his subjects' hearts to persuade them of what he wants. He called them comrades to remove any border that may impede his direct interaction with them. Lear aims to gain the support of his people in his war against his daughters and their husbands. The king, who is used to force his people to work on the wall day and night, is now calling the same people as loyal comrades to get closer to them because he wants to win their support. The nonverbal effect of the king in his march with the army represented in his waving to his people is also a mark which shows the king's intention to narrow the gap between him and his subjects in order to gain their support.

\section{Findings and Discussion}

Based on the above analysis, this paper demonstrates a number of findings as follows:

\subsection{Manipulative and Persuasive Power in Bond's Lear}

A CDA of Bond's Lear shows the realization of the two types of power, i.e. manipulative and persuasive power on the lexical and pragmatic levels of analysis. The following table shows the presence (+) and absence (-) of CDA strategies as markers of manipulative and persuasive power in Bond's Lear in terms of the two levels of analysis. 
Table 1. Strategies of manipulative and persuasive power in Bond's Lear

\begin{tabular}{|c|c|c|c|}
\hline Level of analysis & CDA's strategy & Power as manipulation & Power as persuasion \\
\hline \multirow[t]{8}{*}{ Lexical } & Euphemism & + & - \\
\hline & Myth-making & + & - \\
\hline & Positive self-presentation & & \\
\hline & Competency & - & + \\
\hline & Promises & + & - \\
\hline & Negative other-presentation & & \\
\hline & Accusation & + & - \\
\hline & Criticism & - & + \\
\hline \multirow[t]{7}{*}{ Pragmatic } & Face-threatening acts & & \\
\hline & Off-record & - & + \\
\hline & Positive politeness & - & + \\
\hline & Negative politeness & - & + \\
\hline & Other politeness strategies & & \\
\hline & Rhetorical questions & + & - \\
\hline & Gap-bridging & + & - \\
\hline
\end{tabular}

Table 1 above shows that on the lexical level manipulative power is realized by means of CDA's strategies, including euphemism, myth-making, positive self-presentation (promises), and negative other presentation (accusation), whereas persuasive power is communicated by means of two CDA's strategies: positive self-presentation (competency), and negative other-presentation (criticism). The table also clarifies that power is pragmatically employed to communicate manipulation by virtue of rhetorical questions and gap-bridging, while its persuasive dimension is represented by off-record strategies, positive politeness and negative politeness. Obviously, this indicates that manipulative power, on the one hand, is more representative in the lexical level (4 occurrences out of 6 ) than in the pragmatic one (2 occurrences out of 5). Persuasive power, on the other hand, is more representative in the pragmatic level ( 3 occurrences out of 5$)$ than in the lexical one ( 2 occurrences out of $6)$.

\subsection{Power Relations: Reciprocity and Non-Reciprocity}

The analysis clarifies that power is used in the selected play to achieve persuasion and/or manipulation. This reconciles with Lakoff's (1982, p. 26) argument that "one important determinant of technically persuasive discourse is non-reciprocity." Lakoff clarifies that a discourse is described to be persuasive, that is, non-reciprocal if all participants are not able to exercise all conversational practices as their counterparts. Conversely, a discourse is described to be non-persuasive; that is, reciprocal if its participants share the ability to have the same conversational options in their communicative practice. Within the context of Lear, practicing power as persuasion and/or manipulation requires one powerful participant that holds the floor and has certain type of control over the communicative act. As such, one can conclude that power as persuasion and power as manipulation are non-reciprocal discursive practices.

\subsection{Power as Ideological Persuasion and/or Manipulation}

The above analysis clarifies that there is a close relationship between persuasion and power in the sense that a great deal of the former depends entirely on the rhetorical dimension of the latter. For Pardo (2001), the criterion upon which one can decide that power is used to persuade or to manipulate depends on certain elements, such as the information used in the argumentation process; that is, if this type of information is based on facts, logic and past experiences, then power targets persuasion. If, on the other hand, this information depends on lies, falsification and brainwashing, then power in this case attempts to manipulate. Thus, there is a triadic relationship between persuasion, manipulation and power; this relationship, for Pardo (2001), leads to the suggestion that using power, whether in the form of persuasion or manipulation, aims to address social values of groups not specific benefits of individuals. Power, in the context of this paper, is socialized and politicized towards a particular ideological agenda that is group-oriented. Consequently, power in its manipulative and persuasive dimensions, always entails an ideology that is intended to be communicated through discourse, and functions to legitimize, institutionalize or, sometimes, disguise that power.

Within the framework of power, those who are powerful (i.e., rhetorically) tend to persuade and manipulate their recipients by influencing their minds and limiting their freedom of action. Powerful participants usually control the course of discourse and have the ability to limit the discourse rights of others by using strategies of 
manipulation and/or persuasion. It is noteworthy to mention that not all forms of power are realized through using force. Other manipulative and persuasive devices are employed to exercise power in discourse. These devices may adopt different dimensions rather than the physical, for example, financial, political or rhetorical. In the present paper, using power is manipulatively- and/or persuasively-based. Thus, the study of power within the framework CDA concentrates on analyzing the influence of the powerful over the powerless. This influence may appear either physically; that is, in the form of coercion which is supported by Partington's (2003) argument that power is used to coerce rather than to persuade, or cognitively; that is, in the form of persuasion and manipulation, which is reinforced by van Dijk's (1996, p. 85) emphasis that a great deal of power in modern democratic societies is practiced persuasively and manipulatively rather than coercively.

\section{Conclusion}

This paper provided a lexico-pragmatic analysis of power as manipulation and power as persuasion in Edward Bond's Lear within the framework of critical discourse analysis. The analysis of the selected play showed the existence of two types of power: manipulative and persuasive; both of them are based on the rhetorical dimension of power. The paper identified two types of discourse in the selected play. Each type is characterized by different linguistic features that are relevant to the production of power relations. There are the discourse of oppression and the discourse of revolt. Manipulative power is more representative in the discourse of oppression than in the discourse of revolt, whereas persuasive power is more representative in the discourse of revolt than in the discourse of oppression. This indicates that Bond succeeds in employing the appropriate linguistic devices that cope with the appropriate type of discourse.

The analysis displayed that persuasive power uses arguments that often depend on facts, logic and past experiences. Its main concern is to illuminate the recipients into adopting an attitude that serves the benefits of both speakers and hearers. The analysis further clarified that manipulative power is realized when misleading or irrelevant information is presented in a way that decreases the public's understanding of the addressed issues. This type of power makes use of arguments that depend on telling lies, falsification, and brainwashing. The primary concern of this type is to manipulate the recipients into complete compliance to the speaker's views even if they contradict the recipient's own interests. This type produces a controlled-will recipient who is rhetorically manipulated to adopt the speaker's attitudes.

The analysis of Bond's Lear also demonstrated the integration of various linguistic levels with CDA, which proves that $\mathrm{CDA}$ is a multidisciplinary approach that allows the integration of different linguistic levels of analysis to achieve its goals. This paper shows the integrated effectiveness of the lexical and the pragmatic levels in the production of persuasive and manipulative types of power in the selected play. Lexically, manipulative power is communicated by means of CDA's strategies that include euphemism, myth-making, positive self-presentation (promises), and negative other presentation (accusation), whereas persuasive power is channeled by virtue of two CDA's strategies: positive self-presentation (competency), and negative other-presentation (criticism). Pragmatically, power is utilized to communicate manipulation through rhetorical questions and gap-bridging, while its persuasive dimension is represented by off-record strategies, positive politeness and negative politeness. This indicates that power is realized by using CDA tools on the level of the word (lexically) and on the level of the utterance (pragmatically).

Finally, for future research, this paper recommends an extensive study of power relations in another literary genre (e.g., the narrative), by applying the same lexico-pragmatic approach to critical discourse analysis. This could reveal findings similar to or different from what is approached in this paper. Also recommended is the study of power in discourse by applying other levels of linguistic analysis (e.g., the semantic or the syntactic). This might be contributive, both theoretically and analytically, in approaching the theme of power in discourse in general, and in literary genres in particular.

\section{Acknowledgements}

This research project was supported by the Deanship of Scientific Research at Prince Sattam bin Abdulaziz University under the research project No. 2019/02/9889.

\section{References}

Allan, K., \& Burridge, K. (1991). Euphemism and dysphemism. Language used as shield and weapon. Oxford: Oxford University Press.

Barthes, R. (1972). Mythologies (A. Lavers Trans). New York: The Noonday Press.

Billig, M. (2003). Critical discourse analysis and the rhetoric of critique. In G. Weiss, \& R. Wodak (Eds.), Critical discourse analysis: Theory and interdisciplinarity (pp. 35-46). Palgrave Macmillan Ltd. 
https://doi.org/10.1057/9780230514560_2

Bloor, T., \& Bloor, M. (1995). The functional analysis of English: A Hallidayan approach. London \& New York: Arnold.

Blum-Kulka, S. (1997). Discourse pragmatics. In T. A. van Dijk (Ed.), Discourse as social interaction. Discourse studies: A multidisciplinary introduction (Vol. 2, pp. 38-63). Sage Publications.

Bond, E. (1978). Lear. In Plays Two. London: Eyre Methuen.

Brembeck, L. W., \& Howell, S. W. (1952). Persuasion: A means of social control. Prentice-Hall, INC.

Brown, P., \& Levinson, S. (1987). Politeness: Some universals in language use. Cambridge: Cambridge University Press. https://doi.org/10.1017/CBO9780511813085

Charteris-Black, J. (2005). Politicians and rhetoric. The persuasive power of metaphor. Palrave Macmillan. https://doi.org/10.1057/9780230501706

Edelman, M. (2001). The politics of misinformation. Cambridge: Cambridge University Press. https://doi.org/10.1017/CBO9780511612640

Fairclough, N. (1995). Critical discourse analysis: The critical study of language. London \& New York: Longman.

Fairclough, N. (2010). Language and power. London \& New York: Longman.

Fairclough, N. (2013[1989]). Language and power (2nd ed.). London \& New York: Longman.

Fairclough, N., Pardo, S., \& Szerszynski, B. (2003). Critical discourse analysis and citizenship. In A. Bora, \& H. Hausendorf (Eds.), Constructing citizenship (pp. 1-17). John Benjamins.

Fairclough, N., \& Wodak, R. (1997). Critical discourse analysis. In T. van Dijk (Ed.), Discourse as social interaction: Discourse studies: A multidisciplinary introduction (Vol. 2, pp. 258-284). Sage.

Flood, C. G. (1996). Political myth: A theoretical introduction. New York \& London: Garland.

Flowerdew, J. (1999). Face in cross-cultural political discourse. In Text: An interdisciplinary journal for the study of discourse (Vol. 19-1, pp. 3-23). Berlin. https://doi.org/10.1515/text.1.1999.19.1.3

Fowler, R. (1996). On critical linguistics. In C. Caldas-Coulthard, \& M. Coulthard (Eds.), Texts and practices: Readings in critical discourse analysis (pp. 15-31). London \& New York: Routledge.

Hirschberg, S., \& Hirschberg, T. (Eds.) (1999). The politics of everyday language. In S. Hirschberg, \& T. Hirschberg (Eds.), Reflections on language (pp. 375-376). New York \& Oxford: Oxford University Press.

Jowett, G., \& O’Donnell, V. (1992). Propaganda and persuasion (2nd ed.). London \& Newbury Park: Sage.

Khafaga, A. (2017a). Discourse interpretation: A deconstructive reader-oriented approach to critical discourse analysis. International Journal of Applied Linguistics \& English Literature, 6(2), 138-146. https://doi.org/10.7575/aiac.ijalel.v.6n.2p.138

Khafaga, A. (2017b). Linguistic manipulation of political myth in Margaret Atwood's The Handmaid's Tale. International Journal of English Linguistics, 7(3), 189-200. https://doi.org/10.5539/ijel.v7n3p189

Lakoff, R. T. (1982). Persuasive discourse and ordinary conversation, with examples from advertising. In D. Tannen (Ed.), Analyzing discourse: Text and talk (pp. 25-42). Georgetown University Press.

Mey, J. (1993). Pragmatics: An introduction. Oxford: Blackwell. https://doi.org/10.1080/10350339309384418

Pardo, M. L. (2001). Linguistic persuasion as an essential factor in current democracies: Critical analysis of the globalization discourse in Argentina at the turn and at the end of the century. Discourse \& Society, 12(1), 91-118. https://doi.org/10.1177/0957926501012001006

Partington, A. (2003). The linguistics of political argument: The spin-doctor and the wolf-park at the White House. London \&New York: Routledge. https://doi.org/10.4324/9780203218259

Pridham, F. (2001). The language of conversation. London \& New York: Routledge.

Schaffner, C. (2004). Political discourse analysis from the point of view of translation studies. Journal of Language and Politics, 3(1), 117-150. https://doi.org/10.1075/jlp.3.1.09sch

Short, M. (1996). Exploring the language of poems, plays and prose. London \& New York: Longman.

Stark, F. M. (1996). Communicative interaction, power and the state: A method. University of Toronto Press. 
Thomas, J. (1995). Meaning in interaction: An introduction to pragmatics. London \& New York: Longman.

van Dijk, T. A. (1989). Structures of discourse and structures of power. In J. A. Anderson (Ed.), Communication yearbook (Vol. 12, pp. 18-59). Newbury Park, C A: Sage. https://doi.org/10.1080/23808985.1989.11678711

van Dijk, T. A. (1993). Principles of critical discourse analysis. Discourse \& Society, 4(2), 249-283. https://doi.org/10.1177/0957926593004002006

van Dijk, T. A. (1995). Power and the news media. In D. Paletz (Ed.), Political communication and action (pp. 9-36). Cresskill, NJ: Hampton Press.

van Dijk, T. A. (1996). Discourse, power and access. In C. Caldas-Coulthard, \& M. Coulthard (Eds.), Texts and practices: Readings in critical discourse analysis (pp. 84-104). London \& New York: Routledge.

van Dijk, T. A. (1997a). Political discourse and racism: Describing others in western parliaments. In S. H. Riggins (Ed.), The language and politics of exclusion: Others in discourse (pp. 31-64). Thousand Oaks, CA: Sage.

van Dijk, T. A. (Ed.) (1997b). Discourse as interaction in society. In Discourse as social Interaction: Discourse studies: A multidisciplinary introduction (Vol. 2, pp. 1-37). Sage.

van Dijk, T. A. (2000). On the analysis of parliamentary debates on immigration. In M. Reisigl \& R. Wodak (Eds.), The semiotics of racism: Approaches to critical discourse analysis (pp. 85-103). Vienna: Passagen Verlag.

van Dijk, T. A. (2001a). Critical discourse analysis. In D. Schiffrin, D. Tannan, \& H. Hamilton (Eds.), The handbook of discourse analysis (pp. 352-392). Blackwell.

van Dijk, T. A. (2001b). Discourse, ideology and context. Folia Linguistica, 35(1-2), 11-40. https://doi.org/10.1515/flin.2001.35.1-2.11

van Dijk, T. A. (2014). Discourse and knowledge: A sociocognitive approach. Cambridge: Cambridge University Press. https://doi.org/10.1017/CBO9781107775404

Weiss, G., \& Wodak, R. (Eds.) (2003) Critical discourse analysis: Theory and interdisciplinarity. Palgrave Macmillan Ltd. https://doi.org/10.1057/9780230288423

Widdowson, H. G. (2007) Discourse analysis. Oxford: Oxford University Press.

Wodak, R., \& Meyer M. (Eds.) (2001). Methods of critical discourse analysis. London: Sage. https://doi.org/10.4135/9780857028020

Yule, G. (1996a). Pragmatics. Oxford: Oxford University Press.

Yule, G. (1996b). The study of language (2nd ed.). Cambridge: Cambridge University Press.

\section{Copyrights}

Copyright for this article is retained by the author, with first publication rights granted to the journal.

This is an open-access article distributed under the terms and conditions of the Creative Commons Attribution license (http://creativecommons.org/licenses/by/4.0/). 